\title{
一臓器反射スペクトル法和よびレーザードップラー法による検討一
}

$\begin{array}{lrll}\text { 板倉 } & \text { 勝 } & \text { 松崎 } & \text { 松平 } \\ \text { 渡辺 } & \text { 光行 } & \text { 門阪 } & \text { 利雄* }\end{array}$

要旨：臟器反射スペクトル法とレーザードップラー法により，腹腔鏡下に慢性肝疾患における 肝組織血行動態を測定した。臓器反射スペクトル法で測定した肝組織局所へモグロビン量は肝 硬変においては低值であった。これに対して, 酸素飽和度とレーザードップラー法による血流 量は肝硬变で増加していた。一方，組織酸素消費能は肝疾患群で著明に低下し，低下が著明な 群では，KICG，血清コリンェステラーゼ，フルブミンも低值を示した．以上より，(1) 肝疾患 における肝組織血行動態の把握に，両測定法による測定が有用であること，(2) 進行した肝疾 患では, 組織内動脈血流量は増加しているにもかかわらず肝組織局所へモグロビン量は低下し ており，組織酸素消費能低下の結果肝代謝能が悪化することが示唆された.

卖引用語：慢性肝疾患肝血行動態葴器反射スペクトル法

$$
\text { レーザードップラー法 }
$$

\section{鍺 言}

進行した慢性肝疾患では，肝組織における血行障害 が病態の成立に深く関与している。すむなわち, 肝硬変 症においては再生結節による肝静脈圧迫, bridging necrosis と線維化部位における肝内シャントの発生, 類洞の毛細血管化などに伴って，門脈王の京進と有効 肝血流量の减少が生じる。このような状態における肝 組織での血行障害と酸素需給障害については, 臓器反 射スペクトル法を用いてへモグロビン動態の面から追 求した研究が既に佐藤らにより報告されている( 研究では蔵器反射スペクトル法とレーザードップラー 法を用いて，慢性肝疾患に怙ける肝組織内血行動態の 变化をへモグロビン，赤血球動態および組織酸素消費 能を測定することにより明らかにして、これらの病態 と肝代謝機能との関連を検討した。

\section{对象と方法}

慢性活動性肝炎 (CAH) 33例, 肝硬変 (LC) 17例を 対象とした。診断は腹腔鏡並びに肝生検病理組織所見 によって確定した，対照として組織学的および血㾞生 化学的な異常が軽烈な慢性持続性肝炎 6 例と, 肝血管 腫患者 3 例の非腫場部肝での計測値を用いた。

*東海大学医学部付属東京病院消化器肝荿病ヒンター 内科

〈受付日1991年11月14日＞
組織へモグロビン量（Hb Index）および組織へモク ロビン酸素飽和度 $\left(\mathrm{So}_{2}\right.$ Index $)$ の測定 : 腹腔鏡はオピ スタン $35 \mathrm{mg}$, 硫酸フトロピン0.5mg の筋注, およびジ アゼパム5〜10mgの静注を前投薬として，局所麻醉下 に通常の方法でおこなった，施行時に右鎖骨中線と右 前腋窩線の間の第 $6 \sim 8$ 胁間から径 $3 \mathrm{~mm}$ のトラカー ルを刺入し，外套を通してまず烚器反射スペクトル測 定装置（TS200，住友電工）のブローブ(径 $2.4 \mathrm{~mm}$ ) を插入した。先端を肝右葉表面に軽く接触させて， Sato らの方法に準じて Hb Index と $\mathrm{So}_{2}$ Index を測 定した。すなわち， Hb Indexは oxyhemoglobin と deoxyhemoglobin の等吸収点 $569 \mathrm{~nm}$ のスペクトル強 度 $\Delta \mathrm{Er}\left(569\right.$-650) を用い， $\mathrm{So}_{2}$ Indexは 2 つの等吸 収点 $569 \mathrm{~nm}, 586 \mathrm{~nm}$ と oxyhemoglobin の $\alpha$ ピーク 577 $\mathrm{nm}$ を利用して下記の式により算出した.

$\mathrm{So}_{2}$ Index $=0.673 \times \mathrm{A} / \mathrm{B}$

A：577nmにおける oxyhemoglobinのスペクトル 強度

$\mathrm{B} ： 569 \mathrm{~nm}$ と $586 \mathrm{~nm}$ のスペクトル強度差 なお，標準白色物質にはBaSO、を使用した。

組䄉酸素消費能 $\left(\mathrm{O}_{2}-\mathrm{C}\right.$ Index $)$ の測定: 䁍器反射 ペクトル測定装置のプローブで肝表面を強く圧迫し， 血流を途絶させた後の局所残留赤血球内へモグロビン 酸素飽和度の低下を連続的に測定し，次式により1分 


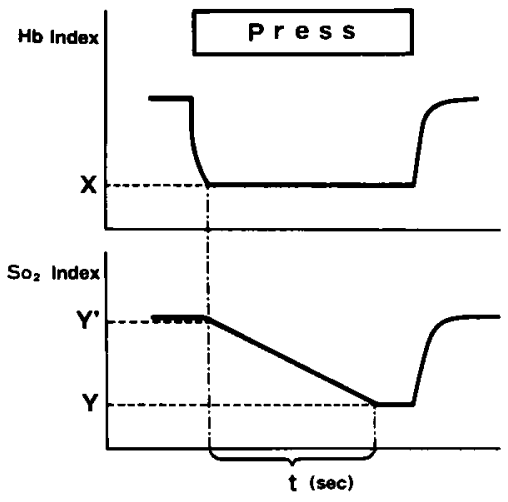

Fig. 1 Measurement of oxygen consumption index $\left(\mathrm{O}_{2}-\mathrm{C}\right.$ Index $)$ by organ reflectance spectrophotometry. The liver surface was pressed by the optical fiber probe to block regional blood flow. $\mathrm{O}_{2}$-C Index was calculated from the residual hemoglobin (X) and the difference oxygen saturation before and after pressing $\left(Y^{\prime}-Y\right)$, and was expressed as the amount of consumption per minute.

間の酸素消費能を $\mathrm{O}_{2}-\mathrm{C}$ Index として求めた (Fig. 1).

$$
\mathrm{O}_{2} \cdot \mathrm{C} \text { Index }=\frac{\mathrm{X} \times\left(\mathrm{Y}^{\prime}-\mathrm{Y}\right) \times 60}{\mathrm{t}}
$$

$\mathrm{X}$ ：圧迫時 $\mathrm{Hb}$ Index

$\mathrm{Y}$ : 压迫時 $\mathrm{So}_{2}$ Index

$\mathrm{Y}^{\prime}$ : 压迫前 $\mathrm{So}_{2}$ Index

$\mathrm{t}$ : 圧迫時間（秒）

レーザードップラー血流計による血流量 (LDV) の 測定：腹腔鏡下に前述のトラカール外套よりレーザー ドップラー血流計(Peri Flux PF3, Perimed)のプロー ブ(径2.4mm)を扦入して肝表面に接触させ perfusion unit を Volt 表示で経時的に測定, ペンレコーダ(SS・ 100F, SEKONIC) で記録した。

统計学的な有意差の検定はnon-paired Student's t-test を用い，成績は平均值士標準偏差で表示した。

\section{成 績}

1) 末梢血へモグロビン濃度と組織へモグロビン量 との関俰 (Fig. 2)

末梢血へモグロビン濃度と組織へモグロビン量は弱 いながらも正の相関を示した。

2) 組織へモグロビン量 (Hb Index) (Fig. 3)

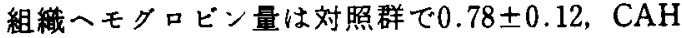
で0.76士0.15であったが，LCでは0.68土0.12であり， 対照群と比較して有意に低值（p<0.05）であった。

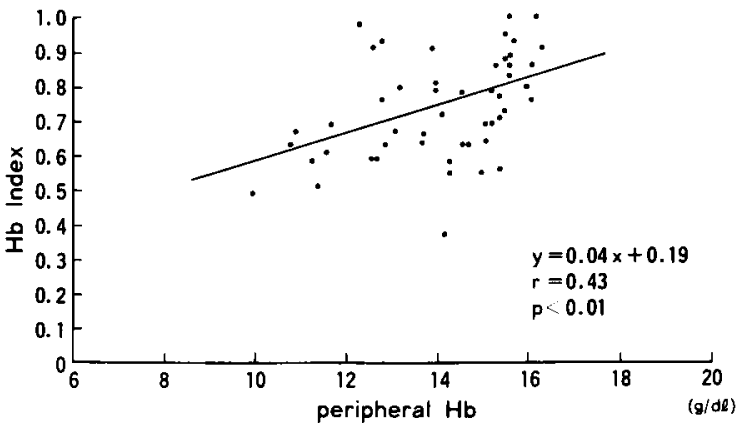

Fig. 2 Correlation between peripheral hemoglobin concentration and $\mathrm{Hb}$ Index.

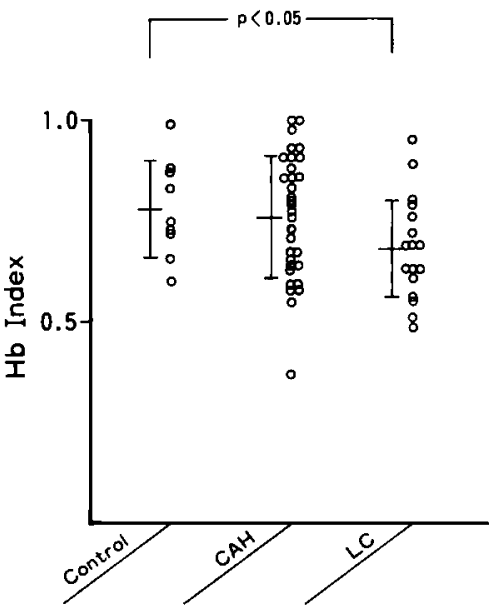

Fig. $3 \mathrm{Hb}$ Index in liver diseases.

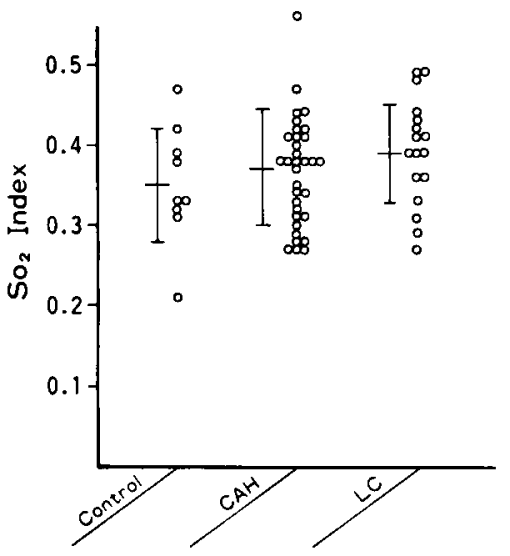

Fig. $4 \mathrm{So}_{2}$ Index in liver diseases.

3）組織酸素飽和度（ $\mathrm{So}_{2}$ Index）(Fig. 4)

組織酸素飽和度は, 対照群の0.35 00.07 と比較して, 


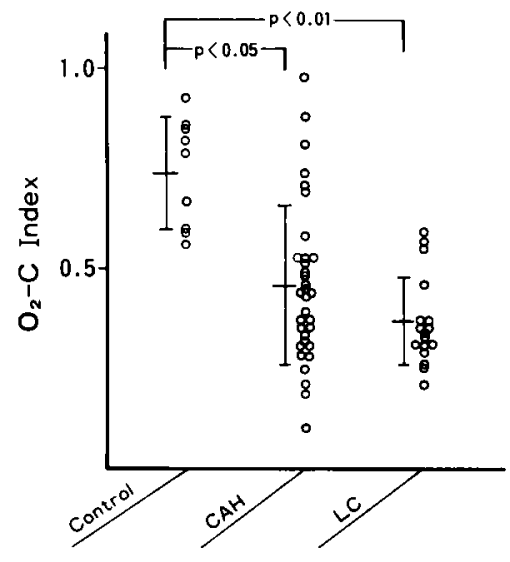

Fig. $5 \mathrm{O}_{2}-\mathrm{C}$ Index in liver diseases.

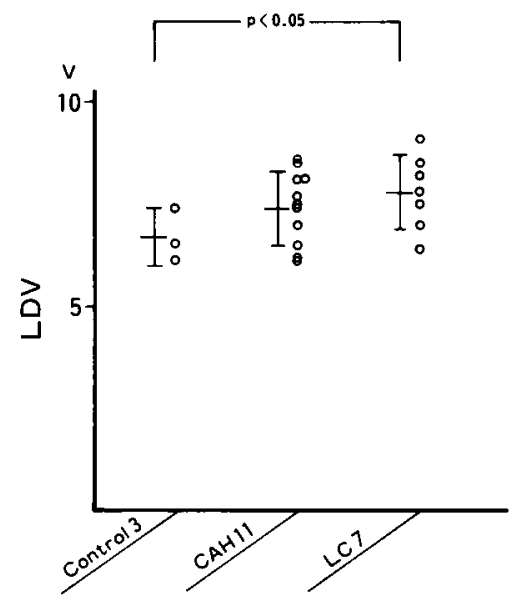

Fig. 6 Laser Doppler velocimetry (LDV) in liver diseases.

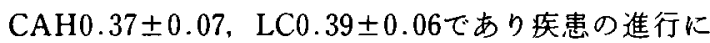
伴い高值をとる傾向があった。

4) 組織酸素消費能 $\left(\mathrm{O}_{2}-\mathrm{C}\right.$ Index ) (Fig. 5)

組織酸素消費能は対照群では0.74士0.14であった。 $\mathrm{CAH}$ では0.46士0.20 と有意に低值を示した（p< 0.05).しかし，Fig. 5 に示すことくこの群には対照群 と変わらない値を示す例と，次に述べる LCに匹敵す る高度低下例がふくまれており，きわめて広い測定值 分布を示していた，LCでは0.37士0.11であり，著明な 低值を示した（ $\mathrm{p}<0.01 ）$.

5) レーザードップラー血流計による血流量 (LDV) (Fig. 6)

一部の症例で施行したレーザードップラー血流計を 用いての測定では，血流計は対照群の $6.7 \pm 0.7 \mathrm{~V} に$ 比
Table Influence of oxygen consumption on $\mathrm{K}_{\mathrm{ICG}}$ serum cholinesterase and albumin in liver diseases.

\begin{tabular}{|c|c|c|c|}
\hline & $\begin{array}{l}\text { Grade I } \\
(n=6)\end{array}$ & $\begin{array}{l}\text { Grade II } \\
(n=12)\end{array}$ & $\underset{(\mathrm{n}=32)}{\text { Grade III }}$ \\
\hline $\mathrm{K}_{1 \mathrm{CG}}$ & $0.168 \pm \underbrace{0.024}_{\mathrm{p}<}$ & $\begin{array}{l}0.135 \pm 0.020 \\
\llcorner .01\lrcorner p<\end{array}$ & $0.117 \pm 0.040$ \\
\hline $\operatorname{ChE}(\mathrm{IU})$ & $4.891 \pm 1.287$ & $4,655 \pm 1.201$ & $\begin{array}{l}3.804 \pm 1.258 \\
.05\end{array}$ \\
\hline $\begin{array}{l}\text { Albumin } \\
\qquad(\mathrm{g} / \mathrm{d} l)\end{array}$ & $3.9 \pm \underbrace{0.6}$ & $\begin{array}{l}3.7 \pm 0.3 \\
-p<0.05\end{array}$ & $\stackrel{3.6 \pm 0.4}{\longrightarrow}$ \\
\hline
\end{tabular}

較して, CAH 7.4 $\pm 0.9 \mathrm{~V}$, LC $7.8 \pm 0.9 \mathrm{~V}(\mathrm{p}<0.05)$ で疾患の進行につれて増加した。

6) 組織酸素消費能と肝代謝機能との関連 (Table)

症例を組織酸素消費能の低下の程度により3群に分 けた。すなわち，対照群の $\left[\mathrm{O}_{2} \cdot \mathrm{C}\right.$ Index の平均一標準 偏差]以上を Grade I (正常群)とし，さらにこの標準 偏差の幅により下に示すごとくGrade II（軽度低下 群）と，Grade III（著明低下群）とに症例を分類して 検討した。

Grade I : $0.60 \leqq \mathrm{O}_{2}-\mathrm{C}$ Index

Grade II : $0.46 \leqq \mathrm{O}_{2} \cdot \mathrm{C}$ Index $<0.60$

Grade III : $\mathrm{O}_{2}-\mathrm{C}$ Index $<0.46$

このようにして群別した 3 群における $\mathrm{K}_{\mathrm{ICG}}$ は, Table に示すごとく，酸素消費能が低下するに従い有意に低 下した．肝での蛋白合成能の指標として用いたコリン エステラーゼは酸素消費能の低下にともない有意に低 下した，血清アルブミンも同様であった。

\section{考案}

蔵器反射スペクトル法は佐藤ら”により開発され， 可視光を用いて組織中のへモグロビンを解析して組織 レベルでの酸素の動態を知るために用いられている. さらに，局所をプロープで圧迫して血流を途絶させ， 酸化へモグロビンから還元へモグロビンへの変化率を 知ることによって，局所での酸素消費能を知ることが 可能とされている.このようにして測定された酸素消 費能は，類洞に括ける肝細胞数と，肝細胞自身の呼吸 能だけでなく，局所における血液量, 赤血球と肝細胞 間における酸素移行状況などの影響を反映するもので あり, in vivoにおける肝微小循環動態を知るらえでき わめて有用之考えられる。一方，レーザードップラー 法は, レーザー光を用いて微小循環中の運動赤血球に より散乱されたレーザー光のドップラー周波数偏移に より，血流量に比例する parameterを得る方法であ 
る. 本法で求められる血流量の parameter は運動赤血 球の平均流速と運動赤血球密度の積に比例する ${ }^{4}$. 初 期の測定装置では肝のような赤血球密度の高い葴器に 対しては血流量が過小評価される欠点があったが，今 回用いた装置では parameter の補正がおこなわれて 肝においてす血流量の測定が可能となった5)。しかし， 本法を臨床に応用して肝疾患患者の血行動態を検討し た成綪はみられない，本法を用いての測定は肝表面か ら約 $0.5 \mathrm{~mm}$ 以内の深さまでを対象としており ${ }^{61}$, 藏器 反射スペクトル分析装置の場合とほぼ同様である7゙. レーザードッブラー法で測定される血流量が，前述の 蔵器反射スベクトル法と根本的に異なる点は，本法て の血流量があくまで運動赤血球を対象としている点て あり、この特改をふまえたうえで，両者の方法により 肝組織血行動態を考える必要があろう。

炡器反射スペクトルの分析で測定した組織へモグロ ビン量は，末梢血へモグロビン濃度と相関しており， 末梢血での負血は，肝組織内へモグロビン量に影響を 与えることが明らかである。しかし，末梢血へモグ口 ビン濃度が正常であっても組織へモグロビン量が低値 である症例，逆に賓血が存在しながらあ組織へモグロ ビン量が維持されている症例があり（Fig. 2)，組織へ モグロビン量のみらず, 局所赤血球動態，酸素動態に ついても検討しなければならない。

組織へモグロビン量は対照に比較して肝硬变で低值 を示したが，組織酸素飽和度は逆に肝硬変で高値の傾 向であった．Sato ら²は慢性肝炎から肝硬变に病变が 進行するに従って肝組織のへモクロビン量が低下する ことを述へ，組織酸素飽和度は組織へモグビン量が 0.55 以上の場合は維持されるものの，0.55未満では低 下していると報告している．Fig. 2，3の示すごとく， 今回の研究で対象とした症例の多くは，たと之肝硬変 であっても組織へモグロビン量が0.55を越えており， それ故に組織酸素飽和度には疾患による明らかな差が 認められなかったるのと考光られる。一方，レーザー ドッブラー血流計で測定した肝組織血流は，葴器反射 スペクトル分析装置で測定した組織へモグロビン量と は逆に肝硬变で増加していた，異なった二つの測定装 置による湘定値の差異は，それぞれが測定している血 流 parameterの差によるすのと考えられる。すなわ ち、惦器反射スベクトル分析装置が肝局所に存在する 全ての赤血球のへモグロビン量を測定しているのに対 して，レーザードッブラー血流計では，肝局所に存在 する運動赤血球の密度と速度が測定対象である。この
二つの測定法により得られた結果を対比することによ ク, 本研究の対象となった肝硬変症例では, 組織へモ グロビン量は減少しているが，赤血球速度あるいは運 動赤血球密度は増加していることがあきらかとなっ た.この所見は肝組織血流に敊ける動脈血の関与比率 の増大を示唆するものである。その程度を知るうえで レーザードップラー血流計による測定が有用であると 考えられた。このような動脈血成分の増加にもかかわ らず，肝硬変では肝組織へモグロビン量が低下してい ることは，動脈血の混入が類洞における血流量低下を 代償することができない病態であることを強く示㗪す るものである。また，これらの症例では臓器反射スぺ クトル分析装置で測定した組織酸素飽和度が対照と比 較して維持されるかあるいは增加していた。この変化 の原因としては，組織酸素消費能の低下に伴万局所血 液の酸素飽和度の増加に加え，レーザードッブラー血 流計による測定で示㖫された動脈血混入の増加の影響 が考えられる。

組織酸素消費能は，各疾患において，対照と比較し てあきらかに低下し，とくに肝硬変でより低下してい た。これらの症例を組織酸素消費能の障害の程度に応 じて 3 群に分けて検討したところ， $\mathrm{K}_{\mathrm{I} C G}$ 上組織酸素消 費能との間に密接な関連が認められた。すなわち，有 効肝血流量の低下が酸素消費能の低下の重要な一因と して深く関与していることが示㖫された．今回の方法 で測定される組織酸素消費能を規定する因子として は，肝細胞数や肝細胞自身の呼吸能のみならす，赤血 球内へモグロビンから肝細胞への酸素の移行速度，あ るいは肝細胞を灌流しないシャント血流の影響等が考 えられる。慢性肝炎から肝硬変へと病変が進行した場 合にむ肝細胞自身の呼吸能は保たれている゙〉さされて いるか，細胞壊死と線維増生により，単位容積当りの 細胞数が減少するために, プロープで圧迫される部位 の細胞数は减少する。ささらに，赤血球から肝細胞への 酸素の移行には，両者の間に存在する類洞と Disse 腔 の病的変化が影響を及ぼす可能性がある。すなわち， 肝硬变に打ける類洞内皮細胞小孔の減少と狭小化 ${ }^{88}$, Disse 腔へのコラーゲン沈着"は，物質交換の阻害だけ でなく酸素消費能の低下をももたらすと考えられる。 また，肝細胞を灌流しないシャント内の赤血球が局所 に存在する場合には測定される酸素飽和度の变化が少 なく酸素消費能はさらに低值を示すこととなる，この ような酸素消費能の低下は，コリンエステラーゼとフ ルブミンの低下と密接に関連していることから，酸素 
消費能の測定は肝に括ける物質代謝機能の評価に有用 である。

本研究の一部は文部省科学研究費の補助によった，本研 究の要旨は第26回および27回日本肝贜学会総会において発 表した。

$$
\text { 文献 }
$$

1) 传藤信紘, 鎌田武信, 七里元亮, 他：急性胃病変の 成因に関する検討。日消誌 $75: 1-8,1978$

2) Sato N, Hayashi N, Kawano S, et al: Hepatic hemodynamics in patients with chronic hepatitis or cirrhosis as assessed by organreflaectance spectrophotometry. Gastroenterology $84: 611-616,1983$

3) Kamada $T$, Hayashi $N$, Sato $N$, et al: Estimated hepatic oxygen consumption in patients with chronic liver diseases as assessed by organ reflectance spectrophotometry. Dig Dis Sci 31 : 119-124, 1986
4) Nilsson GE, Tenland T, Oberg PA: Evaluation of a laser Dopper flowmeter for measurement of tissue blood flow. IEEE Trans Biomed Eng 27 : 597-604, 1980

5) Arvidsson D, Svensson H, Haglund U : LaserDoppler flowmetry for estimating liver blood flow. Am J Physiol G471-G476, 1988

6) Stern MD, Bowen PD, Parma R, et al: Measurement of renal cortical and medullary blood flow by Laser-Doppler spectroscopy in the rat. Am J Physiol 236 : F80-F87, 1979

7) Sato N, Kamada $T$, Shichiri $M$, et al: Measurement of hemoperfusion and oxygen sufficiency in gastric mucosa in vivo. Gastroenterology $76: 814-819,1979$

8）江口尚久：ヒトおよび実験的肝硬変における肝類 洞の電䫒的観察。肝臓 $18: 803-813,1977$

9) Phillips JM, Steiner JW : Electron microscopy of cirrhotic nodules. Lab Invest $15: 801-817$, 1966

\title{
Influence of impaired tissue hemodynamics on hepatic function in chronic liver diseases -Evaluation with organ reflectance spectrophotometry and laser Doppler velocimetry-
}

\author{
Masaru ITaKURA, Shohei Matsuzaki, Kouichi SHIRAISHI, \\ Mitsuyuki Watanabe and Toshio Kadosaka*
}

Tissue hemodynamics of the liver was studied in chronic liver diseases with organ reflectance spectrophotometry and laser Doppler velocimetry under laparoscopy. Tissue hemoglobin was decreased in liver cirrhosis, although blood flow measured with laser Doppler velocimetry and oxygen saturation were increased in this group. Oxygen consumption was significantly decreased in liver diseases. $K_{I C G}$, serum cholinesterase and albumin were significantly decreased in patients with severely impaired oxygen consumption. The present data suggest (1) measurement of tissue blood flow and oxygen consumption with organ reflectance spectrophotometry and laser Doppler velocimetry is useful for the evaluation of tissue hemodynamics of the liver in chronic liver diseases, and (2) in advanced liver disease, tissue hemoglobin was decreased despite increase of inflow of arterial blood, and decreased tissue oxygen consumption resulted in impaired metabolic function of the liver.

\footnotetext{
* Department of Internal Medicine, Center of Gastroenterology and Hepatology, Tokai University School of Medicine, Tokyo Hospital (Tokyo)
} 